\title{
Erratum to: Patterns of decline in upper limb function of boys and men with DMD: an international survey
}

Mariska M. H. P. Janssen • Arjen Bergsma •

Alexander C. H. Geurts · Imelda J. M. de Groot

Published online: 8 June 2014

(C) Springer-Verlag Berlin Heidelberg 2014

Erratum to: J Neurol

DOI 10.1007/s00415-014-7316-9

Unfortunately, the online published article has errors in Table 5. The correct table is given in the following page.

The online version of the original article can be found under doi:10.1007/s00415-014-7316-9.

M. M. H. P. Janssen $(\bowtie) \cdot$ A. Bergsma .

A. C. H. Geurts · I. J. M. de Groot Department of Rehabilitation, Radboud University Medical Center, Donders Centre for Neuroscience, Reinier Postlaan 4, 6525 GC Nijmegen, The Netherlands

e-mail: mariska.janssen@ radboudumc.nl 
Table 5 Social participation per disease stage

\begin{tabular}{|c|c|c|c|c|c|}
\hline & Total & $\begin{array}{l}\text { Early } \\
\text { ambulatory } \\
\text { stage }\end{array}$ & $\begin{array}{l}\text { Late } \\
\text { ambulatory } \\
\text { stage }\end{array}$ & $\begin{array}{l}\text { Early } \\
\text { non-ambulatory } \\
\text { stage }\end{array}$ & $\begin{array}{l}\text { Late } \\
\text { non-ambulatory } \\
\text { stage }\end{array}$ \\
\hline \multicolumn{6}{|l|}{ Participants } \\
\hline Going to school (\%) & 78 & 91 & 96 & 96 & 59 \\
\hline$N$ & 200 & 58 & 27 & 24 & 91 \\
\hline Working (\%) & 11 & 2 & 4 & 4 & 20 \\
\hline$N$ & 198 & 56 & 27 & 24 & 91 \\
\hline Playing sports (\%) & 38 & 50 & 30 & 33 & 35 \\
\hline$N$ & 198 & 56 & 27 & 24 & 91 \\
\hline Having a hobby (\%) & 83 & 66 & 89 & 92 & 89 \\
\hline$N$ & 198 & 56 & 27 & 24 & 91 \\
\hline In a romantic relationship (\%) & 3 & 0 & 0 & 0 & 7 \\
\hline$N$ & 197 & 55 & 27 & 24 & 91 \\
\hline \multicolumn{6}{|l|}{ Participation restrictions } \\
\hline $\begin{array}{l}\text { Experiencing limitations of the arms and/or hands during school } \\
\text { activities }(\%)^{\mathrm{a}}\end{array}$ & $68 / 14$ & $63 / 2$ & $85 / 0$ & $78 / 4$ & $59 / 35$ \\
\hline$N$ & 154 & 51 & 26 & 23 & 54 \\
\hline $\begin{array}{l}\text { Experiencing limitations of the arms and/or hands during work } \\
\text { activities }(\%)^{\mathrm{a}}\end{array}$ & $62 / 14$ & $100 / 0$ & $100 / 0$ & $100 / 0$ & $56 / 17$ \\
\hline$N$ & 21 & 1 & 1 & 1 & 18 \\
\hline Experiencing limitations of the arms and/or hands playing sports $(\%)^{\mathrm{a}}$ & $66 / 16$ & $75 / 0$ & $88 / 0$ & $50 / 25$ & $56 / 31$ \\
\hline$N$ & 76 & 28 & 8 & 8 & 32 \\
\hline Experiencing limitations of the arms and/or hands during hobbies $(\%)^{\mathrm{a}}$ & $60 / 7$ & $46 / 0$ & $58 / 0$ & $45 / 0$ & $70 / 15$ \\
\hline$N$ & 164 & 37 & 24 & 22 & 81 \\
\hline $\begin{array}{l}\text { Experiencing limitations of the arms and/or hands in a romantic } \\
\text { relationship }(\%)^{\mathrm{a}}\end{array}$ & $33 / 33$ & - & - & - & $33 / 33$ \\
\hline$N$ & 6 & 0 & 0 & 0 & 6 \\
\hline
\end{tabular}

a Participation: first number = percentage of respondents that experienced mild participation restrictions due to UE limitations; second number $=$ percentage of respondents that experienced severe participation restrictions due UE limitations. The rest percentage is the percentage of respondents that answered to experience no limitations in the arms and/or hands (percentage not shown in table) 